\title{
IMPLEMENTASI E-MENTORING \\ UNTUK MENINGKATKAN KOMPETENSI GURU PEMULA \\ DALAM MEMBUAT VIDEO PEMBELAJARAN
}

\author{
MILAINI \\ Pengawas SMP Kota Batam \\ Email:milainimila68@gmail.com
}

\begin{abstract}
ABSTRAK
Tujuan Penelitian adalah melalui implementasi E-Mentoring dapat meningkatkan kompetensi guru dalam membuat video pembelajaran di SMP Negeri Binaan Kecamatan Sekupang Kota Batam Tahun 2020. Metode yang digunakan dalam penelitian ini adalah penelitian tindakan sekolah (PTS). penelitian ini telah dilaksanakan di 4 Sekolah binaan kota batam. Waktu pelaksanaan kegiatan ini dilakukan secara daring mengunakan bantuan jejaring sosial menggunkan WA, dan aplikasi Microsoft Foms, Teams dengan pelaksanaan dilakukan tanggal 13 Mei 2020 sampai tanggal 20 Juni 2020. Sabjek sasaran adalah guru pemula yang berjumlah 18 Guru Teknik Pengumpulan Data yang digunakan adalah teknik observasi dengan instrument lembar observasi penilaian kompetensi guru pemula dalam membuat video pembelajaran. Teknik Analisis Data yang digunakan adalah analisis deskriptif kuantitatif. Dari hasil pelaksanaan dinyatakan bahwa E-Mentoring Video Pembelajarann dapat meningkatkan kemampuan guru pemula dalam menyusun video pembelajaran di SMP Binaan Kota Batam sebesar 84\% dengan kategori baik.
\end{abstract}

Kata Kunci : Metode Pembelajaran, E-Mentoring, Video Pembelajaran

\section{PENDAHULUAN}

Berdasarkan Surat Edaran Kementerian Pendidikan Dan Kebudayaan Republik Indonesia Nomor 4 Tahun 2020 Tentang Pelaksanaan Kebijakan Pendidikan Dalam Masa Darurat Penyebaran Corona Virus Disease (Covid -19) dan Surat Edaran Walikota Batam Nomor 181 Tahun 2020 Tentang Peningkatan Kewaspadaan Terhadap Resiko penularan Infeksi Corona Virus Disease (Covid- 19) dan Surat Edaran Dinas Pendidikan Kota Batam Nomor 181/DISDIK/IV/2020 Tentang Peningkatan Kewaspadaan Terhadap Resiko penularan Infeksi Corona Virus Disease (Covid-19) dan Kegiatan Belajar Mengajar Dari Rumah maka kegiatan yang berhubungan dengan segala aktivitas dunia pendidikan di kota batam mengalami pembatasan..

Akibatnya Pembelajaran dilakukan dengan daring. Dunia pendidikan menjadi berubah 180 derajat. Karena satu satunya solusi yang bisa ditawarkan dengan melakukan pembelajaran daring (online learning/ online class room). Selain itu juga Akibat wabah Corona Virus Disease (Covid-19) memberikan shock therapy bagi Pengawas Sekolah, Kepala Sekolah, Guru dan Siswa untuk meningkatkatkan kompetensi dalam bidang penguasaan Teknologi dan Informasi (TIK). Berkenaan dengan penyebaran Corona Virus Disease (Covid-19) yang semakin meningkat maka kesehatan lahir dan batin siswa, guru, kepala sekolah dan seluruh warga sekolah menjadi pertimbangan utama dalam pelaksanaan kebijakan pendidikan. Terkait tugas pengawas sekolah yang harusnya dilaksanakan secara periode dan tatap muka dalam pelaksanaan pembimbingan berbasis manual tidak dapat dilaksanakan pada masa pendemi Corona Virus Disease (Covid-19) kepada kepala sekolah, guru senior maupun kepada para guru pemula.

Program pembimbingan untuk guru pemula yang disebut program induksi merupakan salah satu tugas pengawas sekolah,. Melalui program ini dapat membantu guru pemula dapat menyesusaikan diri dengan tugas barunya dan dapat meningkatkan keprofesionalan dalam bidangnya. Sudradjat, A (2010) mengatakan program induksi ini merupakan sebuah kegiatan pelatihan , orientasi, pengembangan diri dan bagaimana memecahkan permasalahan ketika melakukan proses pembelajaran di tempat tugasnya. Induksi guru pemula adalah psoses 
orientasi kegiatan mengajar di satuan pendidikan dalam konteksnya,dimana dalam tahun pertama mengajar guru pemula mendapatkan pembelajaran professional di tempat kerjanya dan tahap awal Pengembangan Keprofesian Berkelanjutan (PKB).

Program Induksi Guru Pemula (PIGP) Permendiknas Nomor 27 tahun 2007 : adalah adalah kegiatan orientalis, pelatihan di tempat kerja, pengembangan praktik dan pemecahan masalah dalam proses pembelajaran / bimbingan dan konseling, bagi guru pemula pada sekolah / madarasah di tempat tugasnya. Dengan demikian program induksi untuk guru pemula ini adalah sebuah program dari pemerintah untuk guru pemula agar mendapatkan orientasi , pendampingan, pembimbingan, pelatihan, pengembangan diri dan bagaimana prakti dalam memecahkan permasalahan yang dihadapai ketika melaksankan tugasnya sebagai guru.

Dalam Permendikbud No.15 Tahun 2018 disebutkan berkomunikasi dengan guru pemula, memberikan pembimbingan ataupun pembinaan dalam melakukan observasi pelaksanaan proses KBM adalah sebuah proses pembimbingan dan pelatihan. Murti (2015) menyatakan pada abad 21 ini Pola pendidikan dituntut untuk menjamin siswa memiliki keterampilan menggunakan teknologi dan media informasi, serta berinovasi dan dapat berkerja, bertahan dengan menggunakan keterampilan untuk hidup (life skilla). Dengan mengintegrasikan Teknologi Informasi dan komunikasi (TIK) dalam kegiatan pembelajaran guru dapat menciptakan pembelajaran yang kreatif dan inovatif dalam membekali siswa mengembangkan dirinya memilki keterampilan literasi informasi, literasi media maupun literasi TIK

Guru wajib memanfaat TIK dalam kegiatan pembelajaran karena terkait dengan ranah kompetensi Pedagogik, juga untuk pengembangan diri yang berkaitan dengan kompetens inti guru dalam ranah kompetensi Profesionalisme, dan ini jelas tercantum dalam Permendiknas Nomor 16 tahun 2007 tentang Standar Kualifikasi Akademik dan Kompetensi Guru. Faktanya Terkait dalam pelaksanaan pengawasan sekolah ditemukan berbagai kendala pada guru pemula di SMP Binaan Kota Batam khusunya dikecamatan Sekupang seperti belum maksimal mengembangkan bahan ajar dalam membuat video pembelajaran sesuai kondisi sekarang, guru pemula cenderung berasumsi membuat pembelajaran TIK memerlukan waktu dan keterampilan khusus dalam membuatnya, sehingga guru pemula belum berminat dan merasa terbebani dalam membuat video pembelajaran.

Bagi guru pemula dalam membuat video pembelajaran terkadang belum sesuai standar yang baik seperti belum maksimalnya keterkaitan kompetensi dan tujuan yang harus dicapai dengan konten materi yang disajikan oleh guru pemula. Selain itu dalam membuat video pembelajaran guru pemula masih monoton dan kurang memperhatikan aspek estetika seperti tampilan grafis, animasi pembelajaran, musik, Beberepa guru pemula dalam mengisi dubbing materi atau konten pembelajaran masih mengunnakan intonasi dan nada yang disampiakan terkadang masih terlalu cepat dan kurang tepat.

Guna mengatasi permasalahan kompetensi guru pemula dalam membuat video pembelajaran yang belum optimal dilakukan E-mentoring. Kata E-mentoring terdiri atas 2 kata yaitu Elekktonik dan Mentoring. Elektronik menurut KBBI adalah benda yang menggunakan alat-alat yang bekerja atas dasar elektronika atau benda yang dibuat berdasarkan prinsip elektronika. Sedangkan istilah mentoring berasal dari bahasa Inggris arti pembimbingan. Dan dalam Kamus Besar Bahasa Indonesia kata bimbing berarti petunjuk cara mengerjakan sesuatu, tuntutan, pimpinan. Menurut Anderson dan Shannon (1998), mentoring adalah sebuah proses alami dimana seseorang yang lebih banyak memiliki kemampuan dan pengalaman melayani sebagai peran model, guru, sponsor, pendorong,konsultan dan teman kepada seseorang yang memiliki kemampuan dan pengalaman masih sedikit.

Sedangkan menurut Kasper (2002), mentoring adalah hal khusus berkaitan dengan pengawasan, hubungan yang saling mendukung atau partnership di antara dua orang yang didasarkan ada kepercayaan dan saling menghargai. Sedangkan Kurniawati (2015), mentoring merupakan proses pembelajaran, dimana mentor mampu membuat mentee (peserta mentoring) yang tadinya tergantung menjadi mandiri. Mentoring adalah bantuan secara 
tersembunyi (offline help) dari mentor ke mentee untuk transfer pengetahuan, pemikiran dalam kerja secara signifikan.

Dapat disimpulkan bahwa E-mentoring adalah sebuah proses pembelajaran dalam bentuk hubungan saling mendukung dan pengawasan, diantara dua orang atau lebih dimana seseorang dianggap memiliki kemahiran dan kemampuan lebih dari yang lain yang disebut mentor menjadi model, guru, sponsor, konsultan dan pendorong kepada peserta mentoring yang disebut mantee dalam rangka mentransfer pengetahuan dan pemikiran agar kompetensi mantee menjadi lebih berkembang yang dilaksanakan mengunakan dan melalui alat yang dibuat berdasarkan prinsip elektronika.

Adapun tujuan penulisan adalah melalui implementasi E-Mentoring untuk meningkatkan kompetensi guru dalam membuat video pembelajaran di SMP Negeri Binaan Kecamatan Sekupang Kota Batam Tahun 2020. Melalui kegiatan E-Mentoring diharapkan bermanfaat bagi Siswa mendapatkan layanan pendidikan yang bermutu selama pendemic Virus Corona dan Menghilangkan kejenuan belajar secara daring. Bagi gurubermanfaat mendapat pengetahuan pembuatan bahan ajar digital yang menarik, terbantu dalam upaya meningkatkan kinerja selama Work From Home (WFH). Bagi Kepala Sekolah bermanfaat membantu dalam pembinaan/pendampingan guru pemula selama Work From Home (WFH) dan bagi Pengawas bermanfaat meenghasilkan model pembelajaran digital terhadap guru, berupa pembuatan video menarik dari slide PPT.

\section{METODE PENELITIAN}

Metode yang digunakan dalam penelitian ini adalah penelitian tindakan sekolah (PTS). E-Mentoring guru pemula dalam menyusun video pembelajaran ini telah dilaksanakan di 4 Sekolah binaan kota batam yaitu SMP Negeri 3 Batam, SMP Negeri 20 Batam, SMP Negeri 25 Batam dan SMP 56 Batam. Waktu pelaksanaan kegiatan ini dilakukan secara daring mengunakan bantuan jejaring sosial menggunkan WA, dan aplikasi Microsoft Foms, Teams dengan pelaksanaan dilakukan dengan 3 x pertemuan yaitu pertemuan ke 1 tanggal 13 Mei 2020, pertemuan ke 2 tanggal 1 Juni 2020 dan pertemuan ke 3 tanggal 20 Juni 2020.

Sabjek sasaran adalah guru pemula yang berjumlah 18 Guru dengan rincian 3 Guru Pemula SMP Negeri 3 Batam, 6 Guru Pemula SMP Negeri 20 Batam, 8 Guru Pemula SMP Negeri 25 Batam dan 1 orang guru pemula SMP Negeri 56 Batam. Prosedur penelitian yang dilaksanakan dimulai dari tahap persiapan, pelaksanaan, evaluasi dan refleksi. Teknik Pengumpulan Data yang digunakan adalah teknik observasi dengan instrument lembar observasi penilaian kompetensi guru pemula dalam membuat video pembelajaran. Teknik Analisis Data yang digunakan adalah analisis deskriptif kuantitatif.

\section{HASIL DAN PEMBAHASAN}

Hasi pra tindakan sebelum dilakukan E-Mentoring kepada guru pemula sasaran di 4 SMP Binaan menunjukan bahwa dari 18 orang guru pemula baru ada sebanyak 2 orang yang membuat video tetapi sangat sederhana dan monoton, suara dan musik tidak ada (mengaktifkan otak kiri dan kanan), Gambar tidak focus, Karakter video tidak sesuai dengan proses pembelajaran penyampaian materi tidak interaktif dan Inovasi serta kreasi belum optimal. Langkah-langkah dalam penerapan E-Mentoring guna meningkatkan kompetensi guru pemula dalam membuat video pembelajaran yaitu:

1. Tahap Persiapan

1) Pengawas berperan sebagai E-mentoring menyusun RPDA dan RPDM

2) Menyapkan instrument/kreteria penilaian video pembelajaran secara daring (Microsoft Foms, Teams dll)

3) Melalui Wa Membuat group dan mengundang mantee (guru) gabung di Teams Microsoft office 365

4) Penjelasan tentang maksud dalam kegiatan ini

5) Menugaskan peserta menyiapkan PPT dan instrument musik 
6) Membuat kesepakatan jadwal pertemuan secara daring

2. Tahap Pelaksanaan

1) Pertemuan 1

a. Membimbing peserta langkah-langkah membuat video pembelajaran dari slide PPT.

b. Berdiskusi

c. Memberikan video tutorial pembuatan video pembelajaran kepada mantee (guru) di Teams, sebagai acuan agar peserta dapat mencoba secara mandiri dan pembuatan video pembelajaran digital, mengupload hasilnya di Teams dan menyepakati pertemuan kedua.

2) Pertemuan 2

a. Mantee (guru) mempresentasikan video mereka (diwakili 3 mantee/guru).

b. mantee (guru) mengamati dan membuat catatan kesil tentang video pembelajaran yang ditayangkan mantee (guru) lain.

c. Mendiskusikan feedback yang belum dipahami oleh mantee (guru).

d. Tindak lanjut diadakan perbaikan-perbaikan atau penyempurnaan video pembelajaran yang pertama.

e. Video Pembelajaran yang sudah disempurnakan di opload ke teams dan Wa

f. Mantee (guru) memberikan penilaian terhadap video pembelajaran mantee (guru) lain, masing-masing menilai 4 peserta dengan menggunakan instrument sederhana yang sudah disiapkan dan diopload di Teams

3) Pertemuan 3

a. Berdiskusi tentang hasil video yang sudah disempurkan.

b. Mentoring memverivikasi dan mengkomvirmasi hasil penilaian video pembelajaran masing-masing mantee (guru).

c. Mentering mengajak mantee (guru)untuk mereview kegiatan yang telah dilakukan dan menyimpulkan

d. Evaluasi, refleksi, dan umpan balik.

1. Tahap Penilaian (Tahap Evaluasi)

1) Penilaian: Keaktifan mantee (guru), produk video pembelajaran dari slide PPT

2) Instrumen: Daftar checklist

\section{Tahap Refleksi (Tahap Rencana Tindak Lanjut)}

1) Menggunakan Video Pembelajaran yang sudah dihasilkan digunakan untuk KBM secara daring.

2) Membuat video pembelajaran yang baru disesuaikan dengan situasi pandemic covid 19 dan Merevisi kegiatan daring agar lebih efektif dan berhasil.

Hasil yang diperoleh dari tindakan untuk mengatasi permasalahan terkait kompetensi guru pemula dengan cara E-Mentoring dalam menyusun video pembelajaran dengan hasil yang diperoleh dari 18 guru di 4 SMP Binaan terdapat 10 guru pemula di SMP binaan yang memiliki kompetensi dengan kategori sangat baik dalam menyusun video pembelajaran, 5 guru pemula di SMP binaan yang memiliki kompetensi dengan kategori baik dalam menyusun video pembelajaran dan 3 guru pemula di SMP binaan yang memiliki kompetensi dengan kategori cukup baik dalam menyusun video pembelajaran. Sedangkan hasil rekapitulasi telaaah video pembelajaran dari 18 guru pemula di SMP Binaan dapat dilihat pada tabel 1 berikut ini. 
Tabel 1. Rekapitulasi Hasil Telaah Video Pembelajaran

\begin{tabular}{|c|c|c|}
\hline NO & INDIKATOR/JENIS PENILAIAN & HASIL \\
\hline 1 & $\begin{array}{l}\text { Gaya dan organisasi (susunan): Konten dalam video } \\
\text { tersusun dan mengalir. Ada hubungan timbal balik yang } \\
\text { logis dan efektif antar "adegan" }\end{array}$ & 91 \\
\hline 2 & $\begin{array}{l}\text { Konten: Subjek dalam video diperkenalkan atau dijelaskan } \\
\text { sehingga audiens dapat dengan mudah mengikuti materi } \\
\text { yang disampaikan }\end{array}$ & 86 \\
\hline 3 & $\begin{array}{l}\text { Kreativitas : } \\
\text { - Penggunaan sudut kamera } \\
\text { - Efek suara atau music } \\
\text { - Pengambilan gambar dalam jarak dekat menarik } \\
\text { perhatian audiens }\end{array}$ & 81 \\
\hline 4 & $\begin{array}{l}\text { Kualitas : } \\
\text { - } \text { Suara seperti musik dan ucapan cukup keras dan } \\
\text { stabil untuk didengar audiens } \\
\text { - } \quad \text { gambar dalam video fokus, pencahayaan yang } \\
\text { sesuai } \\
\text { - } \\
\text { pengambilan video stabil }\end{array}$ & 77 \\
\hline 5 & $\begin{array}{l}\text { Isi video bersesuaian dengan tugas / aktivitas belajar yang } \\
\text { diberikan pada siswa }\end{array}$ & 79 \\
\hline 6 & Karakteristik vedio sesuai dengan proses pembelajaran & 86 \\
\hline 7 & Mampu mendukung isi dan bahan pembelajaran & 87 \\
\hline 8 & Kemudahan dalam pengaksesan & 83 \\
\hline 9 & Durasi video tidak terlalu lama & 79 \\
\hline 10 & Inovasi dan kreasi dalam pembuatan video pembelajaran & 82 \\
\hline 11 & Sesuai dengan keadaan dan kondisi saat ini & 82 \\
\hline 12 & $\begin{array}{lrrr}\text { Kesesuaian video pembelajaran } & \text { dengan kemampuan } \\
\text { berfikir siswa (ringkas, jelas, lugas) } & & \\
\end{array}$ & 89 \\
\hline 13 & $\begin{array}{l}\text { penyajian materi bersifat interaktif, sehingga memotivasi } \\
\text { siswa belajar mandiri }\end{array}$ & 89 \\
\hline 14 & $\begin{array}{l}\text { Secara umum Video pembelajaran mempunyai kualitas } \\
\text { visual (penampilan) dan suara (audio) }\end{array}$ & 89 \\
\hline
\end{tabular}

Peneliti menetapkan indikator keberhasilan adalah tingkat ketercapaian minimal $75 \%$ untuk setiap aspek/indikator dimana persentase ketercapaian diperoleh dari jumlah skor ketercapaian dari setiap skor yang diperoleh guru dalam menyusun video pembelajaran yang memenuhi kriteria dibagi jumlah semua skor ketercapaian dari seluruh guru (skor maksimal). Secara keseluruhan penelitian ini telah mencapai keberhasilan dan sudah mencapai indikator dengan skor/nilai rata-rata yang diperoleh dari 18 guru di SMP Binaan Kota Batam Tahun 2020 yaitu sebesar 84 dengan kategori baik.

Secara Deskriptif kuantitatif terjadi peningkatan implementasi E-Mentoring untuk meningkatkan kompetensi guru dalam membuat video pembelajaran di SMP Negeri Binaan Kecamatan Sekupang Kota Batam Tahun 2020 hal ini dibuktikan terdapatnya peningkatan jumlah guru pemula dari 2 Orang guru pemula yang membuat video pembelajaran menjadi 16 guru pemula yang membuat video pembelajaran. Peningkatan terjadi karena Implementasi EMentoring video pembelajaran bagi guru pemula hebat memiliki keunggulan yaitu: hemat 
biaya dan waktu, meningkatkan motivasi, kemandirian, kreatifitas, dan meningkatkan kompetensi TIK mantee (guru). Selain itu melalui E-mentoring yang terencana guru pemula terbimbing, terpantau dan terevaluasi secara berkala dalam membuat video pembelajaran.

Romansah (2017) menyatakan bahwa mentoring adalah proses umpan balik yang terus menerus dan dinamis antara dua individu untuk membangun hubungan antara individu yang memiliki pengetahuan, keterampilan, informasi dan dengan fokus pada pengembangan profesional dan pribadi. Mentoring merupakan sarana yang di dalamnya terdapat kegiatan pembelajaran. Mentoring bertujuan memberikan dukungan kepada individu sehingga mampu mengatasi masalah yang dihadapi dengan cara menguatkan dan mengembangkan mekanisme baru yang lebih baik untuk mempertahankan kontrol diri dan mengembalikan keseimbangan yang adaptif, sehingga mampu mencari tingkat kemandirian yang lebih tinggi serta mampu mengambil keputusan secara otonom.

Meskipun ada kendala yang dihadapi seperti: (1) Kegiatan E_Mentoring ini menggunakan jaringan internet, sering jaringan tidak stabil dan kegiatan jadi terganggu. (2) Sangat tergantung pada kedisipinan perseta, peserta yang tidak disiplin dan tidak mempunyai motivasi tinggi akan sulit menghasilkan video pembelajaran yang inovasi dan menarik, dan (3) Perlu waktu yang lama meminta tagihan video pembelajaran hasil revisi setelah pembimbingan.

Namun demikian semua masalah tersebut dapat diatasi dengan komunikasi dan koordinasi dan kerjasama yang baik dengan melibatkan kepala sekolah sebagai rekan pengawasan disekolah. Sehingga pembimbingan yang dilakukan dengan cara E-Mentoring kepada guru pemula di SMP Binaan sudah mampu membuat video pembelajaran dari slide PPT, terlihat dari hasil identifikasi video setelah pembimbingan adanya peningkatan yang seknifikan. Keberhasilan ini karena adanya faktor pendukung seperti (1) Kegiatan EMentoring bisa diikuti oleh peserta dimana pun sesuai keinginannya asalkan mempunyai akses internet dan guru pemula diberikan bantuan internet dari pihak sekolah dan pemerintah dalam bentuk bantuan kuota yang menunjang akses pelaksanan e-mentoring, (2) Guru pemula termotivasi untuk merevisi video pembelajaran karena pembimbingan dilakukan tidak hanya lewat micrhosoft team, tetapi lewat WA juga, (3) Mendapat dukungan dan amanah penuh dari Kepala Sekolah sehingga guru harus bertanggung jawab dalam pemenuhan tugasnyanya, Dan (4) Guru berpendapat bahwa video pembelajaran yang dibuat sendiri lebih kontekstual, sesuai tujuan pembelajaran yang diranjang serta sangat membantu guru pemula dalam kegiatan proses pembelajaran terutama pada saat pembelajaran daring ini. Hasil atau dampak yang dicapai dari implemntasi mentoring ini yaitu:

1. Bagi Guru:

1) Guru Pemula termotivasi membuat bahan ajar berupa Video pembelajaran

2) Kompetensi TIK Guru Pemula meningkat

3) Meningkatnya kemampuan dan pemahaman Guru Pemula dalam membuat video pembelajaran dari slide PPT

4) Guru Pemula memilki contoh video pembelajaran yang inovatif.

5) Guru Pemula bisa menjadi agen pengerak dan perubahan dalam memotivasi rekan sejawat yang lainnya untuk membuat video pembelajaran

2. Bagi Siswa:

1) Siswa lebih mudah memahami materi pembelajaran, karena video pembelajaran didukung oleh ilustrasi dan suara

2) Meningkatnya motivasi belajar siswa pada kegiatan pembelajaran terutama secara daring.

3) Kegiatan belajar dan mengajar bagi siswa lebih interaktif dan menarik.

4) Mendapatkan layanan pendidikan yang bermutu terutama selama pandemik Virus Corona ini.

5) Meningkatkan kemampuan berpikir kritis dan kreatif siswa. 
3. Bagi sekolah:

1) Sekolah memilki Pustaka video pembelajaran yang inovatif dan kreatif.

2) Meningkatnya mutu dan citra sekolah dalam pengembangan pembelajaran berbasis digital

Untuk itu guru pemula diharapkan mampu mengembangan kompetensinya dan guru pemula dapat melakukan alternatif pengembangan diri dalam pembuatan video pembelajaran seperti guru mampu berinovasi sesuai kebutuhan membuat Video Pembelajaran dari slide PPT dengan materi yang berbeda-beda sesuai kompetensi dan tujuan pembelajaran yang ingin dicapai dan video pembelajaran dapat dievaluasi agar kompetensi guru pemula semakin lebih meningkat, melakukan kolaborasi dengan rekan sejawat lainnya dalam membuat Video Pembelajaran dari slide PPT yang lebih berkualitas dan lebih menarik. Dengan demikian Ementoring memiliki keunggulan yaitu (1) Hemat biaya dan waktu, (2) Meningkatkan motivasi mantee (guru), (3) Meningkatkan kemandirian mantee (guru) dan (4) Meningkatkan kompetensi TIK mantee (guru).

\section{KESIMPULAN}

E-Mentoring Video Pembelajarann dapat meningkatkan kemampuan guru pemula dalam menyusun video pembelajaran di SMP Binaan Kota Batam sebesar $84 \%$ dengan kategori baik walaupun masih ada 3 orang Guru Pemula memperoleh kompetensi yang cukup baik dalam menyusun video pembelajaran dan masih perlu pembinaan dan mentoring secara intensif. Secara keseluruhan E-Mentoring Video Pembelajaran Tepat Guru Pemula Hebat dapat dijadikan solusi Pengawas Sekolah dalam membina guru pemula untuk meningkatkan kompetensi professional dalam membuat bahan ajar video pembelajaran yang akan digunakan sebagai materi ajar kegiatan pembelajaran online (pembelajaran daring) kepada siswa di Masa Pendemi Corona Virus Disease (Covid-19). Untuk membuat video pembelajaran dapat mengunakan slide power point (PPT) menjadi video pembelajaran yang menarik dan inovatif karena hasil video sesuai kebutuhan, menimbulkan efek seperti bertatap langsung dengan gurunya dan siswa lebih mudah memahami pembelajaran karena didukung oleh ilustrasi dan suara gurunya.

\section{DAFTAR PUSTAKA}

Kamus Besar Bahasa Indonesia (KBBI) Online.

Kasper, Michael. (2002). Information Packet: Mentoring, National Resource Center For Foster Care \& Permanency Planning. New York.

Kurniawati, R.D. (2015). Skripsi: Penerapan Metode Mentoring Pendidikan Agama Islam Terhadap Pembentukan Religiusitas Dimensi Ibadah Pada Siswa SMK Negeri 1 Panjatan Kulon Progo Yogyakarta. Yogyakarta: UIN Sunan Kalijaga.

Murti, K. E. (2015). Pendidikan abad 21 dan aplikasinya dalam pembelajaran di SMK. (2009). Retrieved from http://www.p4tksbjogja.com/images/artikel/Pendidikan_Abad_21_dan_Aplikasinya_dalam_Pembelaja ran_di_SMK_-_Kuntari.pdf.

Peraturan Menteri Pendidikan Nasional Nomor 16 Tahun 2007 Tanggal 4 Mei 2007 Tentang Standar Kualifikasi Akademik Dan Kompetensi Guru.

Peraturan Menteri Pendidikan Nasional Nomor 27 Tahun 2010 Tentang Program Induksi Bagi Guru Pemula.

Permendikbud No.15 Tahun 2018 Tentang Tugas Pokok Pengawas Sekolah.

Romansah, Tatang. (2017). Implementasi Kegiatan Mentoring Keagamaan dalam Pembinaan Karakter Islami. Jurnal Atthulab, Vol. II No.1.

Senom, B., Razak, A.Z., \& Sharatol, S.A.S. (2013). Novice teachers' challenges and survival: where do malaysian esl teachers stand? American Journal of Educational Research, 1(4) 119-125.

Sudrajat, A. (2010). Sekilas tentang program Induksi Guru Pemula (PIGP). 